\title{
Designing Telecollaboration Projects for Developing Intercultural Communicative Competence
}

Kültürlerarası İletişim Yeterliliğini Geliştirmek İçin Uzaktan İşbirliği

Projeleri Tasarımı

\author{
Sedat Akayoğlu \\ Bolu Abant İzzet Baysal University, Turkey \\ Bedrettin Yazan \\ University of Texas at San Antonio, USA \\ Babürhan Üzüm \\ Sam Houston State University, USA
}

\begin{abstract}
As the ways of communication and interaction have diversified thanks to the constantly developing and changing technological possibilities, educators try to do their best to follow the recent implementations and activities to better prepare their students for real world demands. Telecollaboration (aka virtual intercultural exchange) is one of such implementations for language educators and students which is an affordable alternative for study abroad. Through these studies, educators design some tasks and activities for their students in which learners could interact with peers from other contexts synchronously or asynchronously. As one of the outcomes of these projects, educators or researchers plan to develop intercultural communicative competence (ICC) of the learners. In the first part of this paper, the researchers discuss the necessity of intercultural communicative competence in language education by elaborating on the skills that an individual with ICC should have. In the second part, we present the affordances and challenges of telecollaboration projects. In the final part, we unpack some critical issues to be considered in the design of a telecollaboration project. We consider this part as a set of guidelines for researchers planning to engage in telecollaboration as part of their teacher education and research practices.
\end{abstract}

Keywords: telecollaboration, intercultural communicative competence, language teaching, teacher education

Öz

Sürekli gelişen ve değişen teknolojik imkanlar sayesinde iletişim ve etkileșim yolları çeşitlenirken eğitimciler de, öğrencilerini geleceğe daha iyi hazırlamak için güncel uygulama ve etkinlikleri takip ederek ellerinden gelenin en iyisini yapmaya çalışmaktadırlar. Uzaktan işbirliği (diğer adıyla sanal kültürlerarası değişim), dil eğitimcilerin ve öğrencilerin yurtdışındaki bireylerle iletişim amacıyla kullanılabilecek uygun bir alternatif olarak görülmektedir. $\mathrm{Bu}$ projeler aracılığıyla, eğitimciler öğrencilerinin diğer bağlamlardaki akranlarıyla eşzamanlı veya eşzamansız olarak etkileşime girebilecekleri bazı etkinlikler tasarlamaktadırlar. Bu projelerin sonuçları

CUJHSS, December 2021; 15/2: 348-362.

(C) Çankaya University ISSN 1309-6761 Printed in Ankara

Submitted: May 30, 2021; Accepted: October 27, 2021

ORCID\#: 0000-0002-9865-2546; 0000-0002-1888-1120; 0000-0003-4511-7985

akayoglu_s@ibu.edu.tr 
olarak, eğitimciler veya araştırmacılar, öğrencilerin kültürlerarası iletişim yeterliliğini (ICC) geliştirmeyi planlamaktadır. Bu makalenin ilk bölümünde, dil eğitiminde kültürlerarası iletişimsel yeterliliğin gerekliliği tartışılmakta ve bu yeterliliğe sahip bir bireyde olması gereken beceriler listelenmektedir. İkinci bölümde, uzaktan işbirliği projelerinin sunduğu olanaklar ve süreçte yaşanan zorluklardan bahsedilmektedir. Son bölümde ise, bir uzaktan işbirliği projesinin tasarımında dikkate alınması gereken bazı kritik konular açıklanmaktadır. Bu son bölüm, uzaktan işbirliği projesi yürütmeyi planlayan araştırmacılar için bir öneri olarak düşünülmektedir.

Anahtar Kelimeler: uzaktan işbirliği, kültürlerarası iletişim yeterliliği, dil öğretimi, öğretmen eğitimi

\section{Introduction}

Beginning from the late 1990s, the interaction among the people has increased regardless of geographical distances. With the common use of personal computers and increasing Internet connectivity at the beginning of the 21st Century, individuals could find opportunities to communicate with other people who are living in any part of the world. Not only the mobility of electronic devices but also the mobility of individuals has become very common. This change in communication has also influenced the educational settings without any doubt. Nowadays, learners in the classrooms are not isolated from other cultures as they used to be in the previous century. While the communicative competence, which was first theorized by Hymes (277), was considered as the main goal of language teaching towards the end of the 20th Century, new competencies have started to be used in the field of English language teaching (ELT) with the rise of the Internet as a tool for communication and globalization. Byram stated this change as a move from "communicative competence" to "intercultural communicative competence" (177). During the communication, individuals are expected to have intercultural communicative competence (ICC) in order to better understand each other.

\section{Intercultural Communicative Competence (ICC)}

ICC is defined as "the ability to communicate and behave effectively and appropriately in intercultural exchanges and also to handle the psychological demands and dynamic outcomes that result from such exchanges" (Cutting 847). The cultural aspects cannot be ignored in communication dynamics and this interculturality included in communication is considered as an indispensable skill for communicative competence. While language learners are learning an additional language, they should also develop their ICC and should learn how to talk about their own culture and develop awareness of the culture of their potential interlocutors. (Byram 69) identified five knowledge and skills for ICC as (a) knowledge of one's own culture and the interlocutor's culture (savoir), (b) skills of interpreting a document or event from another culture (savoir comprendre), (c) the ability to acquire knowledge of another culture (savoir apprendre), (d) relates to attitudes towards other (savoir etre), and (e) critical cultural awareness (savoir 
s'engager). Individuals should know their own culture, the interlocutors' culture, interpret and acquire knowledge about other cultures, recognize the similarities and differences between the cultural elements and critically evaluate both cultures in an interaction. Additionally, extending Byram's framework, Houghton argued that interculturality should include savoir se transformer (312), i.e., knowing how to develop oneself selectively through interaction with others. ICC framework postulates that using this set of knowledge and skills, language users should be able to "relativize their own beliefs and values, without supposing that they are the only true ways to understand the world and themselves in relation to the world" (Üzüm et al. 12).

In developing the ICC of the learners, the role of the language teachers cannot be underestimated. Teachers should create and provide some opportunities and they should be role models for their learners so that learners could develop their ICC and become global citizens. Taking the importance of ICC for teachers, teacher training programs aimed at developing ICC of pre-service teachers through some courses during the undergraduate programs. For this purpose, courses in most teacher education programs focus on helping teachers develop ICC through class readings and discussions. Typically, some journal articles or videos are assigned to pre-service teachers and they are expected to acquire knowledge about the target culture through discussions and reflection papers. However, these topics are rarely ever negotiated with the members of the target culture. Yet, actual interaction with people from other cultures was found to have a deeper influence on teachers' understanding of intercultural communication (Palmer and Menard-Warwick). As a result, the institutions and organizations, such as universities, and European Union, have attempted to create new platforms to develop the ICC of pre-service teachers. For example, some pre-service teachers applied for the study abroad programs during their undergraduate education. Only a few of them can be supported financially and the ones who are selected for these exchange programs take some courses abroad. The main purpose of these exchange programs is to develop pre-service teachers' ICC along with their academic development. However, as mentioned above, the number of pre-service teachers who could benefit from these programs is very limited. Additional academic community engagement projects are organized and the pre-service teachers can join these projects with their professors. Yet, these projects still need financial funding and they have a considerably shorter time frame than other study abroad projects. Finally, online intercultural exchange projects have become popular because they have some remarkable advantages. For example, they are more affordable when compared to the previously mentioned opportunities. Rather than only reading some materials that mostly include broad generalizations about cultures, preservice teachers could discuss some topics with their interlocutors. Recently, the Internet connection provided by the services is very strong and it allows people to communicate via synchronous video conferences. Finally, pre-service teachers can 
communicate with their partners anytime they like, as long as the time difference allows. Communication is not limited to the class hour.

In the remainder of this paper, we discuss the affordances and challenges of telecollaboration studies. Then, based on our experiences in this field, we will suggest some guidelines for colleagues who are willing to design telecollaboration projects.

\section{Telecollaboration}

Telecollaboration refers to Internet-based collaborative practices for intercultural exchange between individuals from different ethnolinguistic/national backgrounds and geographically remote locations (Guth and Helm). Because of the difficulties and disadvantages of the aforementioned more 'traditional' ways of developing ICC of pre-service teachers, telecollaboration studies have become very popular recently. Considering their affordances, educators, researchers, and institutions have started to invest their time and energy in these studies more than ever.

First of all, these projects help learners to practice their target language extensively. They are exposed to meaningful language interaction and they are actively involved in the learning process. Although these projects start with the purpose of developing ICC of the pre-service teachers, the participants really improve their language proficiency while negotiating meaning with their interlocutors (Angelova \& Zhao 168). Moreover, since they meet online and use the Internet as the medium of communication, they can encounter the Internet language with abbreviations, typos, or incomplete sentences, which are very common in daily life and cannot be found in coursebooks. The excerpts from these studies and some transcriptions can be used as real-world tasks and real-world language materials.

Secondly, as the main purpose of these projects is to develop learners' ICC, the participants could get more detailed and nuanced information about the interlocutor's culture. Typically, in language classes, information about the target culture is usually based on TV shows, films, movies, advertisements, and videos on the Internet. This information usually leads to stereotypes for the learners, although unintentionally. With facilitators' scaffolding, telecollaboration projects provide the space for learners to question and critically evaluate these stereotypes with their peers. Additionally, learners are positioned as experts of their cultures and find a chance to express their ideas and explain their cultural values to their interlocutors. Learners use the language meaningfully to negotiate their ideas and identities, which might be motivating for some learners. In many studies, the authentic use of the language is recommended, and this is a way of using the target language authentically (Berardo; Kılıçkaya; Peacock).

While intercultural learning is considered among many benefits of telecollaboration studies, reflecting on one's own culture is also among the affordances. During the coversations about the similarities and differences 
between one's own culture and the interlocutor's culture, participants would need to reflect on their own culture, which requires individuals to critically evaluate their own culture. In turn, these telecollaborative exchange projects help the participants to create an awareness about themselves.

Finally, the participants could develop the competence to critically evaluate social and political perspectives and practices (Lewis and O'Dowd). If the participants are asked to discuss some critical questions and issues during the telecollaboration, they could evaluate social and political practices in their context. In telecollaboration studies, the participants could find opportunities to reflect on social events from different perspectives. They could see that social problems, such as gender discrimination, inequalities in education and social life, religious issues are not specific for their own culture, but they may be common in other cultures. They could discuss these points with the members of other societies and offer some possible solutions to these problems.

\section{Challenges of Telecollaborative Studies}

The positive results of telecollaboration studies on the participants' attitudes, motivation, professional development, and academic achievements have been discussed in the literature (Angelova and Zhao; Canto, Jauregi and van den Bergh; Chun; Dooly; Hauck; Lee and Markey; Liaw and Bunn-Le Master; Schenker; Ware and Kessler). Yet, the implementation of the intercultural exchange projects does not mean that they always lead to successful outcomes. Due to some factors, these projects may result in failure or they may create some problems both for the participants and the instructors. In the literature, these factors are mainly classified into four categories as "individual, classroom, socioinstitutional, and interaction" (0'Dowd 351; O'Dowd and Ritter 623). These can be specifically associated with the participants, project tasks, the instructors, or the technical difficulties.

The first group of challenges mentioned in the literature is at the individual level and may result from the participants' individual characteristics, attitudes, or motivation (Avgousti; Bueno-Alastuey and Kleban; Fuchs; Hauck and Young; Lee; Melo-Pfeifer; O'Dowd; O'Dowd and Ritter). As a sample to the problems in this category, a group of students may dominate the discussions, and this can be the result of their more advanced technical and linguistic skills. If the medium of the discussions is a 'native' language of one group, the other group may be hesitant to contribute to the discussions in order not to be misunderstood or as a result of insecurity in terms of 'correct' language use. Additionally, O'Dowd found that lack of intercultural competence could affect learners' contribution to the studies and the partner may not maintain an effective correspondence with their peers. Other important individual factors can also be listed as participants' motivation, expectations, and willingness to communicate, which explain most of telecollaborative exchange dysfunctions (Hauck; Ware). Angelova and Zhao suggested that more guidance should be provided for learners and an orientation session could be useful for meeting their partners before the project starts. Another 
challenge in this category is related to commitment - not only for the participants but also for the instructors. These projects usually last for one semester or two semesters which is followed by the data analysis procedure and dissemination of the results. If the participants or the instructor lose motivation, they may get lost in the process. Instructors could integrate the requirements of the project into the class syllabus, especially in the evaluation process. If participants are aware of the fact that their contribution is also evaluated, they will be more motivated; however, the grade points allocated to the project should be considered as bonus and should not be threatening for the participants.

The second group of challenges is at the classroom level and it is associated with the design of the project tasks in terms of their content and evaluation, that is, the classroom procedures as a whole. The intercultural exchange projects are designed as a set of tasks to be completed by the participants in which they could interact, negotiate meaning, and engage in meaningful communication. However, there is little research on the type of tasks that allows more interaction, and these tasks are usually designed by instructors. Harris recommends that collaborative planning by key stakeholders (e.g., teachers and learners) in the online learning experience will foster greater ownership and participation which will reduce the likelihood of abandonment of the work before completion. The objectives of the projects should address the needs and interests of the learners. According to Harris, the content and structure of the activities should be flexible and accommodate customization by participants at each location. Additionally, the content of the tasks should be challenging and engaging. In the literature, scholars (Helm; Ware and Kramsch; O'Dowd) critiqued the content of telecollaboration studies for only including superficial discussion topics (e.g., festivals, food). Discussing such topics, participants tend to find similarities across cultures and perpetuate the stereotypes, rather than experiencing the intercultural tension that could lead to productive learning. However, researchers and educators should allow participants to take part in challenging and discomforting subjects (e.g., gender inequality, minoritized populations, ethnic/religious marginalization). In many parts of the world, there are instances of violence and disrespect in relation to the values of other religions or the views of other people's sexual orientations. For participants to take up productive discussions around such topics, designers need to make sure the tasks will lead participants towards that direction and facilitators need to follow conversations and interject with questions or comments to help participants further contribute to the discussion.

The third group of challenges is at the socioinstitutional level and these challenges are usually beyond participants' control. Intercultural exchange projects usually start with the researchers' initiatives and it is mostly difficult to maintain a balance among the partner groups in terms of study programs, timetables, and participants' language proficiency levels (Belz and Müller-Hartmann; Dooly). As a result of this, the timetables, course, requirements, evaluation procedures, and expectations of 
the participants may vary for different groups in the projects (Bueno-Alastuey and Kleban). Different grading systems were also perceived as problematic and strongly related to participation levels (Bueno-Alastuey and Kleban; Barr). For example, in the previous telecollaboration studies we conducted between preservice teachers from the US and Turkey (Akayoğlu et al.; Üzüm, et al.; Üzüm, et al., Yazan, et. al., Üzüm, et al.), the academic calendar overlapped for only 8 weeks although the semester lasts for 14 weeks for both groups. The US group started their semester almost a month earlier than the group from Turkey, which is why the latter group waited for almost a month to start the project while the former group started as soon as the semester started. These kinds of challenges are also called socioinstitutional factors (O'Dowd; O'Dowd and Ritter) and although they can be out of the researchers' control, they should be taken into account during the design of the projects. Other important points are the content of the activities, the planning of the tasks, and the evaluation criteria of the projects. Participants should be informed whether their contribution is a part of the evaluation component of their courses or what kind of tasks they are expected to complete so that they could be ready for the projects. The technological facilities are considered among the socioinstitutional challenges of online intercultural exchange projects (Fuchs; Hauck and Youngs; Jauregi, de Graaff, van den Bergh and Kriz; Lee; Liaw; Wang and Chang). Although technology-related problems have decreased remarkably in the recent years thanks to the improved quality of the Internet connection in a lot of countries, the widespread use of tools, the fact that both teachers and learners have increased digital literacy skills, there are still some issues caused by technical aspects of telecollaboration. Educators should always keep in mind that technology is not the objective but just a tool, and while selecting the tool, it should be remembered that the tool should address both instructors' and learners' needs. Redmond and Lock noted that "educators who are involved in the design and development of collaborative learning will need to be purposeful in their selection of technology to accommodate the appropriate mode(s) of communication (e.g., synchronous and asynchronous) and bandwidth available to meet the specific learning goals and outcomes" (274).

The final challenge is at the interaction level and this includes the problems related to "the misunderstandings and tension which arise from cultural differences in communicative style and behavior" (O'Dowd and Ritter 634). The participants have different cultural values and they might have some misunderstandings as they work on telecollaboration tasks. For example, in one of our previous studies (Üzüm, et al.), the participants in Turkey and the US had some complaints about unanswered emails while arranging synchronous meetings with their partners. In face to face classrooms, they asked their teachers to contact the teachers of their partners about this issue. As teachers and researchers in that project, we had to remind our students to check their emails. Although this is considered as one of the challenges in telecollaboration studies, facilitating faculty should make sure that these misunderstandings lead to the negotiation of meaning and that project 
participants engage in intercultural learning in such communication breakdowns. Therefore, facilitators play a significant role as they monitor and mediate the interaction that is going on in telecollaboration projects.

As a result, the sources of the challenges might be diverse and if these challenges are addressed carefully, they can be seen as opportunities to develop participants' intercultural competence.

\section{Important Issues for Designing Telecollaboration Studies}

While designing a telecollaborative study, project coordinators would keep in mind some points to maximize the study's benefits. We categorized these important points under five subheadings: (1) finding a partner group, (2) scheduling and time-zone differences, (3) engaging and challenging tasks, (4) required Web 2.0 tools, and (5) outcome. These suggestions are mostly based on the studies we carried out before (Akayoğlu et al.; Üzüm, et al.; Üzüm, et al., Yazan, et. al.); and these suggestions are elaborated with some samples from the data.

\section{Finding a Partner Group}

The very first step and one of the challenging issues in telecollaboration studies is about finding a partner group. The achievement of the project is mainly based on the dynamics created between or among partner groups. While collaborating with a partner school, researchers need to consider learners' language use, time zone differences between contexts, the content of the courses (in which telecollaboration is housed), and learners' perceived educational goals in taking part in telecollaboration.

Learners' creative and strategic language use affects how they contribute to online discussions and participate in activities. We view participants in telecollaboration as multilingual language users without assigning them any proficiency level. They bring in their full langua-cultural repertoires into the intercultural interaction. Their use of language might digress from the 'standard,' which we deem as creative and strategic in their negotiation of meaning. For example, in one of our studies, we have observed that participants could act very creatively by using translingual negotiation strategies in their Edmodo posts when interacting with peers from other cultural contexts (Yazan et al.). However, there were also instances in which participants moved to the next topic or changed the subject without addressing their interlocutors' questions or attending to the need for clarification and further explanation.

Another issue concerns the time-zone difference. In telecollaborative studies, learners are usually expected to meet synchronously on the Internet (preceding or following their asynchronous discussions). Planning those meetings, they need to schedule a time that works for all the group members ( $n=6$ of 7) from two or three countries. As the time difference between those participants' local time zones increases, scheduling becomes more challenging. In our studies (Akayoğlu et al.; 
Üzüm, et al.; Üzüm, et al., Yazan, et. al.), the time difference is 7 or 8 hours. The participants mostly mentioned time-difference as one of the challenges. We see this as part of their intercultural learning; that is, they understand the implications of living in different time-zones. Also, the participants from Turkey realized that most college students in Texas would need to work during the day apart from their studies, which is not very common in Turkey. This experience was also a part of an intercultural learning for both parties.

The course content, in which the project is implemented, is also an indicator of the success in the project because the learners have some expectations from the course content at the beginning of the semester. Since the content of the project primarily centers on culture and related topics, the course should be intended to address similar topics so that there is some consistent interplay between the course content and telecollaboration activities if learners can easily associate the objectives of the project and the teacher education course, which influences learners' motivation in both. In our previous studies (Akayoğlu et al.; Üzüm, et al.; Üzüm, et al.; Yazan, et. al.), the learners in the US were taking a course called Multicultural Education and the ones in Turkey were taking a course called Language and Culture, which were closely related to the tasks they needed to complete in the project. If the curriculum includes no such course specifically on culture and its relationship to language and education, an elective course could be designed if possible.

Finally, learners should share similar expectations from their participation in telecollaborative projects. The partners might be trying to improve their language skills as language users, interested in learning about the culture of their peers, and willing to share their professional learning experiences about teaching. For example, in our studies, the participants were studying to be an English language teacher and improving their ICC was their main goal in the project. They believed that they would be better teachers by developing their ICC; they could better understand the linguistic and cultural diversity in the classroom, and this would affect their teaching profession positively. These overlapping objectives might be helpful to the researcher in motivating the participants in the project.

Recently, some online platforms have been designed to find partners for telecollaboration studies. UNICollaboration (https://www.unicollaboration.org/) is a cross-disciplinary professional organization for telecollaboration and virtual exchange in Higher Education, which was created in 2016. The main objectives of this platform are to "promote the development and integration of research and practice in telecollaboration and virtual exchange across all disciplines and subject areas in higher education" and "actively engage in awareness raising of telecollaboration and virtual exchange at institutional and policymaking level" (UNICollaboration). They organize a bi-annual conference on telecollaboration and virtual exchange; provide a platform to match educators and researchers all around the world. The researchers could add the details of their projects on the website, and the other researchers could contact them if they are interested in their projects. 
Most importantly, they also provide training to support research studies and novice researchers in this area.

\section{Scheduling - Time Zone Difference}

We discussed this issue before as one of the challenges of telecollaborative studies. If researchers could find partners in countries within closer time-zones or the same continent, this challenge would be alleviated. Otherwise, researchers should expect challenges and design their tasks and orient participants accordingly to preempt issues that may arise. For example, in asynchronous discussions, participants might expect quick responses to their posts or questions. Considering the fact that the communication is on the Internet, participants tend to be used to receiving an instant response, so they might grow impatient as they wait for how their comments or questions are responded. In order to overcome this problem, the posting times in asynchronous communication might be clarified before the project, or for synchronous communication, researchers might organize the meeting schedule at the outset of the project. The scheduling is usually not a big problem for one-to-one meetings, but if researchers plan to gather all the participants during the class hours, this might be difficult and sometimes impossible.

\section{Engaging and Challenging Tasks}

Researchers (Helm; Ware and Kramsch; O'Dowd) criticized the tasks that usually focused on the very surface level cultural exchanges, such as clothes, music, food, festivals. These topics might help participants to develop their knowledge about other cultures; however, in ICC, Byram also added some critical perspectives. Individuals with ICC should be able to critique and evaluate their own culture and other cultures. For this purpose, some sensitive topics should be added to the content of the tasks. It would be more successful if participants could develop their ICC on sensitive issues, such as religion/faith, gender discrimination, sexual orientation, minorities, refugees, social justice, political issues, and ethnicities. In one of our studies, we organized 6-week long discussions, and each week we asked some questions on multiculturalism, the role of religion/faith, gender discrimination, and educational policies. Participants included members of different religions, Christianity and Islam, along with some minoritized religious and non-religious perspectives. Some participants engaged in critical evaluation of their own religious beliefs and practices through their discussions.

Yet, researchers should be cautious while asking questions or making comments on these issues. Since these topics are sensitive, researchers should be very knowledgeable about potential concerns of the society and should not use any marginalizing or othering statements during tasks. 


\section{Required Web 2.0 Tools}

Since telecollaborative studies are completely online projects, the features of the tools that we use for communication are crucial. Instead of listing the names of the tools, it could be better to categorize these tools based on their purposes. In a telecollaborative study, we might need four types of tools: (1) a Learning Management System (LMS), (2) asynchronous platform, (3) synchronous platform, and (4) tools for producing materials.

There are many different versions of LMSs, and their features are almost alike. These platforms are utilized to gather participants, make announcements to all participants, share some materials, and create small groups. The determination of the meeting platform will be the first step in a project. Researchers should be very competent in using the features of the chosen LMS. In the second step, participants should be trained in using the platform's features effectively and purposefully. Finally, the guidelines and policies of posting could be determined and announced. For example, in our studies, we use Edmodo (http://www.edmodo.com) as our meeting place. We created a tutorial on Edmodo features and then shared our guidelines and policies. The main wall of the classroom was used just for announcements and by researchers. Participants shared their ideas and work in their small groups so that the main page of the platform was not congested or overloaded.

Secondly, there needs to be an asynchronous platform for discussions. LMSs usually provide such a platform for participants. For example, on Edmodo, users could easily post messages, make comments, like the posts, and share their materials. They are stored on their server, and the data could be accessed later for analysis. The other important point in asynchronous discussions is to divide the participants into groups of 4 or 6 . Such grouping would make the facilitation more manageable and participants can more easily establish rapport in a short time. We usually select two students from each context to form these small groups in our projects so that each context is represented by at least two participants who can bring in diverse approaches or can answer a context-specific question when the other partner is missing. A participant might want to withdraw from the project or be unwilling to participate in discussions. Besides, partners from the same country in small groups might complement each other's contributions during the discussions. Considering these, we believe that creating small groups could improve the content of the conversations.

In addition to asynchronous conversations, participants are usually asked to meet on synchronous platforms. Meeting their partners in a videoconference session appears to be motivating for participants. They could share their ideas instantly. For this purpose, some tools could be used freely. We preferred Zoom (zoom.us), but Google Meet (meet.google.com) and Microsoft Teams (www.microsoft.com/en$\mathrm{ww} /$ microsoft-teams/group-chat-software) could be used as well. The participants should be trained on how to record and share the meeting recordings with the 
researchers. Since researchers cannot attend all one-to-one meetings, participants have to manage technical tools. Before these synchronous meetings, the participants could prepare their questions, or researchers could assign some tasks for those meetings so that participants are actively engaged in some sort of learning throughout the meeting.

Finally, the participants might be asked to produce materials at the end of the project. For example, they might be asked to create a digital story, a short movie, voice recordings, websites, blogs, journals, teaching material, and poster presentations. There are numerous Web 2.0 tools available for varying purposes. Researchers should be knowledgeable about the tools that could be used for creating such materials. Before assigning a task, a tutorial could be prepared for participants, and researchers should help them with any technical challenges.

\section{Outcome}

In many telecollaborative studies, the content is limited to asynchronous discussions, and participants are only asked to share their ideas. The logs of these discussions are collected and analyzed. However, it could be better for participants to produce materials collaboratively at the end of the project. This material might include cultural elements so that they could understand their own and their partners' cultures better. As mentioned above, they could create a digital story using movie clips, design a poster presentation, keep a collaborative blog for reflections, or design a website. In addition to cultural projects, participants could also design some materials based on their professions; for example, in one of our studies, pre-service teachers of English designed lesson plans in collaboration (Yazan et al., 2020). They critiqued and contributed to their partners' lesson plans through reflective conversations. Such collaborative tasks provided them with discursive and experiential spaces to interact with peers interculturally and prepare instructional materials to enhance their students' intercultural learning.

\section{Conclusion}

In this paper, we first discussed the importance and the necessity of ICC. The learners should have ICC competence if they would like to communicate with the members of the other cultures without any misunderstandings and with tolerance. In educational contexts, educators used some ways of developing learners' ICC, such as assigning reading materials, videos and discussing these materials in the classroom settings, because a limited number of students could join international projects and visit other countries and, as an alternative, telecollaboration projects enable the learners to develop ICC. As for the affordances of the telecollaboration studies, learners could practice target language with people whose mother tongue is different, they could develop their ICC, they could also reflect on their own culture and better understand their cultural elements, and they could critically evaluate some social and political perspectives. Second, we discussed the challenges of telecollaboration studies so that researchers could be ready for potential issues. 
These challenges are mostly related to participants, project tasks, instructors, or technical difficulties. Finally, we shared some points which could be considered as guidelines while designing a project, based on our extensive experience in telecollaboration. These issues are related to finding a partner school, time zone differences and scheduling, engaging and challenging tasks, required Web 2.0 tools, and outcome. This paper could be helpful for researchers who would like to implement telecollaboration studies as teacher education pedagogies and conduct research on the data gathered in the implementation.

\section{Works Cited}

Akayoğlu, Sedat, et al. "Preservice teachers' cultural identity construction in telecollaboration." The complexity of identity and interaction in language education, edited by Nathanael Rudolph, Ali Fuad Selvi and Bedrettin Yazan, Multilingual Matters, 2020, pp. 188-205, doi:10.21832/9781788927437-012

Angelova, Maria, and Ying Zhao. "Using an Online Collaborative Project between American and Chinese Students to Develop ESL Teaching Skills, Cross-Cultural Awareness and Language Skills." Computer Assisted Language Learning, vol. 29, no. 1, Taylor \& Francis, 2016, pp. 167-85, doi:10.1080/09588221.2014.907320.

Avgousti, Maria Iosifina. "Intercultural Communicative Competence and Online Exchanges: A Systematic Review." Computer Assisted Language Learning, vol. 31, no. 8, Taylor \& Francis, 2018, pp. 819-53, doi:10.1080/09588221.2018.1455713.

Berardo, Sacha Anthony. "The Use of Authentic Materials in the Teaching of Reading." The Reading Matrix: An International Online Journal, vol. 6, no. 2, 2006, pp. 60-69.

Belz, Julie A., and Andreas Müller-Hartmann. "Teachers as Intercultural Learners: Negotiating German?American Telecollaboration along the Institutional Fault Line." The Modern Language Journal, vol. 87, no. 1, 2003, pp. 71-89, doi:10.1111/15404781.00179.

Bueno-Alastuey, M. C., and M. Kleban. "Matching Linguistic and Pedagogical Objectives in a Telecollaboration Project: A Case Study." Computer Assisted Language Learning, vol. 29, no. 1, 2016, pp. 148-66, doi:10.1080/09588221.2014.904360.

Byram, Michael. From Foreign Language Education to Education for Intercultural Citizenship: Essays and Reflections. Multilingual Matters, 2008.

Canto, Silvia, et al. "Integrating Cross-Cultural Interaction through Video-Communication and Virtual Worlds in Foreign Language Teaching Programs: Is There an Added Value?" ReCALL, vol. 25, no. 1, 2013, pp. 105-21, doi:10.1017/S0958344012000274.

Chun, Dorothy M. "Developing Intercultural Communicative Competence through Online Exchanges." CALICO Journal, vol. 28, no. 2, 2011, pp. 392-419.

Cutting, Joan. "A Thematic Linguistic Analysis of TESOL Students' Commitment to Intercultural Communication Values." TESOL Quarterly, vol. 54, no. 4, 2020, pp. 84669, doi:10.1002/tesq.559.

Dooly, Melinda. "Understanding the Many Steps for Effective Collaborative Language Projects." Language Learning Journal, vol. 36, no. 1, 2008, pp. 65-78, doi:10.1080/09571730801988405.

Dooly, Melinda Ann. "Crossing the Intercultural Borders into 3rd Space Culture(s): Implications for Teacher Education in the Twenty-First Century." Language and Intercultural Communication, vol. 11, no. 4, 2011, pp. 319-37. 
Fuchs, Carolin. “'Are You Able to Access This Website at All?' - Team Negotiations and Macro-Level Challenges in Telecollaboration." Computer Assisted Language Learning, vol. 29, no. 7, 2016, pp. 1152-68, doi:10.1080/09588221.2016.1167091.

Guth, Sarah and Francesca Helm. Telecollaboration 2.0: Language, Literacies and Intercultural Learning in the 21st Century. Peter Lang, 2010.

Harris, J. "Taboo Topic No Longer: Why Telecollaborative Projects Sometimes Fail." Learning and Leading with Technology, vol. 27, no. 5, 2000, pp. 58-61.

Hauck, Mirjam. "Critical Success Factors in a TRIDEM Exchange." ReCALL, vol. 19, no. 2, 2007, pp. 202-23, doi:10.1017/S0958344007000729.

Hauck, Mirjam, and Bonnie L. Youngs. Telecollaboration in Multimodal Environments. 2009, doi:10.1080/09588220801943510.

Helm, Francesca. "The Practices and Challenges of Telecollaboration in Higher Education in Europe." Language Learning \& Technology, 2015, vol. 19, no: 3, pp. 197-217.

Houghton, Stephanie Ann. "Making Intercultural Communicative Competence and Identity-Development Visible for Assessment Purposes in Foreign Language Education." The Language Learning Journal, vol. 41, no. 3, Routledge, Nov. 2013, pp. 311-25, doi:10.1080/09571736.2013.836348.

Hymes, Dell. “On Communicative Competence." Sociolinguistics, edited by J.B. Pride and J. Holmes, Penguin, 1972, 269-293.

Jauregi, Kristi, et al. "Native/Non-Native Speaker Interactions through Video-Web Communication: A Clue for Enhancing Motivation?" Computer Assisted Language Learning, vol. 25, no. 1, 2012, pp. 1-19, doi:10.1080/09588221.2011.582587.

Kılıçkaya, Ferit. "Authentic Materials and Cultural Content in EFL Classrooms." The Internet TESL Journal, vol. 10, no. 7, 2004.

Lee, Lina. "Blogging: Promoting Learner Autonomy and Intercultural Competence through Study Abroad." Language Learning and Technology, vol.15, no. 3, 2011, pp. 87-109.

Lee, Lina and Alfred Markey. "A Study of Learners' Perceptions of Online Intercultural Exchange Through Web 2.0 Technologies. ReCALL, vol. 26, no. 3, 2014, pp. 281-297.

Lewis, Tim and O'Dowd, Robert. "Introduction to Online Intercultural Exchange and This Volume." Online Intercultural Exchange: Policy, Pedagogy, Practice, edited by Tim Lewis and Robert O'Dowd, London: Routledge, 2016, pp. 3-20.

Liaw, Meei-ling. "E-Learning and the development of intercultural competence." Language Learning \& Technology, vol. 10, no. 3, 2006, pp. 49-64.

Liaw, Meei-ling, and Susan Bunn-le Master. Understanding Telecollaboration through an Analysis of Intercultural Discourse. 2010, pp. 20-40, 10.1080/09588220903467301.

Melo-Pfeifer, Sílvia. "Blogs and the Development of Plurilingual and Intercultural Competence: Report of a Co-Actional Approach in Portuguese Foreign Language Classroom." Computer Assisted Language Learning, vol. 28, no. 3, 2015, pp. 220-40, doi:10.1080/09588221.2013.818556.

Barr, David. "Students and ICT: An Analysis of Student Reaction to the Use of Computer Technology in Language Learning." IALLT Journal of Language Learning Technologies, vol. 36, no. 2, 2004, pp. 19-38, doi:10.17161/iallt.v36i2.8408.

O'Dowd, Robert. "Understanding the 'Other Side': Intercultural Learning In A SpanishEnglish E-Mail Exchange." Language Learning \& Technology, vol.7, no. 2, 2003, pp. 118-44. 
O'Dowd, Robert. "Negotiating Sociocultural and Institutional Contexts: The Case of Spanish-American Telecollaboration." Language and Intercultural Communication, vol. 5, no. 1, 2005, pp. 40-56, doi:10.1080/14708470508668882.

O’Dowd, Robert, "Intercultural Communicative Competence Through Telecollaboration", in The Routledge Handbook of Language and Intercultural Communication ed. Jane Jackson (Abingdon: Routledge, 30 Nov 2011 ), accessed 29 Sep 2021 , Routledge Handbooks Online.

O'Dowd, Robert, and Markus Ritter. "Understanding and Working with 'Failed Communication' in Telecollaborative Exchanges.” CALICO Journal, vol. 23, no. 3, 2013, pp. 623-42, doi:10.1558/cj.v23i3.623-642.

Palmer, Deborah K. and Julia Menard-Warwick. "Short-Term Study Abroad for Texas Preservice Teachers: On the Road from Empathy to Critical Awareness. Multicultural Education, vol. 19, no: 3, pp.17-26.

Peacock, Matthew. "The Effect of Authentic Materials on the Motivation of EFL Learners." ELT Journal, vol. 51, no. 2, 1997, pp. 144-56, doi:10.1093/elt/51.2.144.

Redmond, Petrea, and Jennifer V. Lock. "A Flexible Framework for Online Collaborative Learning." Internet and Higher Education, vol. 9, no. 4, 2006, pp. 267-76.

Schenker, Teresa. "Intercultural competence and cultural learning through telecollaboration." CALICO Journal, vol. 29, no. 3, 2012, pp. 449-70.

UNICollaboration. Cross-Disciplinary Organisation for Telecollaboration and Virtual Exchange in Higher Education, 2021, https://www.unicollaboration.org/index.php/about. Accessed 19 July 2021.

Üzüm, Babürhan, et al. "Using Telecollaboration to Promote Intercultural Competence in Teacher Training Classrooms in Turkey and the USA." ReCALL, vol. 32, no. 2, 2020, doi:10.1017/S0958344019000235.

Üzüm, Babürhan, et al. "Preservice' Discursive Constructions of Cultural Practices in a Multicultural Telecollaboration." International Journal of Multicultural Education, no. 1, 2019, pp. 82-104.

Üzüm, Babürhan, et al. “Pre-service teachers' translingual negotiation strategies at work: telecollaboration between France, Turkey, and the USA." Language and Intercultural Communication, vol. 21, no. 6, 2021, doi.org/10.1080/14708477.2021.1981360

Wang, Amber Yayin, and Wan-Jeng Chang. "Developing Intercultural Awareness and Language Speaking Proficiency for Foreign Language Learners through CrossCultural Voicemail Exchange." International Journal of Computer-Assisted Language Learning and Teaching, vol. 1, no. 4, 2011, pp. 17-32.

Ware, Paige D., and Claire Kramsch. "Toward Teaching Intercultural Stance: English through Telecollaboration." The Modern Language Journal, vol. 89, no. 2, 2005, pp. 190-205.

Ware, Paige, and Greg Kessler. "Telecollaboration in the Secondary Language Classroom: Case Study of Adolescent Interaction and Pedagogical Integration." Computer Assisted Language Learning, Taylor \& Francis, 2016, pp. 427-50.

Yazan, Bedrettin, et al. "Telecollaboration as translingual contact zone: teacher candidates' translingual negotiation strategies." TESOL Teacher Education in a Transnational World, edited by Osman Z. Barnawi and Anwar Ahmed, Routledge, 2020, pp. 139157, doi:10.4324/9781003008668-9. 